\title{
AN AFRICAN PHILOSOPHICAL ANALYSIS OF ISAIAH 58: \\ A HERMENEUTIC ENTHUSED BY UBUNTU
}

\author{
Bhele Ndikhokele Mtshiselwa \\ University of South Africa
}

\begin{abstract}
African philosophy is a recognised field both in the Old Testament and philosophy studies in Africa. Jacobus W Gericke argues that "methodological and conceptual debates in African philosophy are things that biblical scholars can learn from when seeking to address the controversy regarding the relationship between the Hebrew Bible and philosophy". On the conceptual debates in African philosophy, Mogobe B Ramose holds that "Ubuntu is not only a word or a concept... On the contrary, Ubuntu is a lived and living philosophy of the Bantu-speaking peoples of Africa". It is argued in this article that African philosophy can shed light on the reading of the ancient biblical text in South Africa, particularly in relation to Ubuntu. First, this contribution examines African philosophy in South Africa with a view to conceptualise a hermeneutic enthused by Ubuntu based on a reading of Isaiah 58. Second, in this article the author attempts to re-construct the Sitz-im-Leben of Isaiah 58 in the light of African philosophy.
\end{abstract}

Key Words: Trito-Isaiah; Sitz-im-Leben; African Philosophy; Ubuntu

\section{Introduction}

... to allow others to articulate their own positions in their own terms and accord them the status of equal partners in the conjoint exploration of a topic, to the extent that we are prepared to allow their views actively to challenge our own 'settled opinion', to modify our preconceptions when they are found wanting, and to learn from what they have to tell us, rather than simply asserting the superiority of our own viewpoint... The point of these postulates is to enjoin us to stop treating those who occupy different discursive standpoints either as mirror images of ourselves or as denizens of a deficient socio-cultural standpoint who need to prove themselves to us before we will accord them a respectful hearing, and instead recognise that they represent a position comparable in value to our own, from which we can productively learn (Healy 2011:302-303; cf. Ramose 2014:134-135).

Based on the preceding argument, the articulation of African philosophy by African people in their own terms, particularly in relation to Ubuntu, renders African philosophy - a well-recognised philosophy - a bold expression of valuable philosophical thoughts of the African people. As Gericke (2009:327) has correctly noted, African philosophy is viewed as not philosophical in the Western technical sense of the word because it comprises dynamic, complex and pluralist clusters of myths, legends, stories, proverbs and songs. However, the same could be said of the Old Testament which also comprises songs, proverbs and stories. This contribution does not aim to argue for the validity of African philosophy or for its articulation on its own terms because African philosophy is a wellrecognised philosophy. Rather, the aim of this article is to illustrate how African 
philosophy can shed light on the reading of the ancient biblical text, specifically of Isaiah 58 , in South Africa, particularly from the viewpoint of Ubuntu.

On the contestation on Ubuntu which is encapsulated in the conflation of African philosophy, Letseka and Venter (2012:4) hold that "Ubuntu is only part of ethno-philosophy". It would be curious to find how one can arrive at this position in light of Ramose's definition of Ubuntu. In what seems to be a clear departure from Letseka and Venter, Ramose (2014:121) convincingly argues that Ubuntu "is not a philosophical abstraction in the fashion of Plato's ideas or forms ... but a lived and living philosophy of the Bantu-speaking peoples of Africa". As a lived and living philosophy, Ubuntu refers to the interconnectedness between human beings which reminds one of the isiXhosa proverb Intaka yakha ngoboya benye, "A bird builds its nest with the feathers of other birds" (Fikeni 2006:237). If "a crucial notion in metaphysics is that of one entity depending for its existence upon another entity - not in a merely causal sense, but in a deeper, ontological sense", as Tahko and Lowe (2015:2) have noted, then the view that Ubuntu is about the interconnectedness between human beings becomes valid. Additionally, if philosophy is a system of thought which guides the way of being and living, in an ontological sense of the word, then when Ubuntu is considered as a philosophy that proceeds from the position that motion is the principle of being, it becomes reasonable to view Ubuntu as a philosophy (cf. Priest 2006:203; Letseka \& Venter 2012:2; Ramose 2014:133).

Gericke and Masenya (ngwan'a Mphahlele) have explored African philosophy within the context of the Hebrew Bible, and these attempts suggest that African philosophy can throw light on the reading of Isaiah 58 in South Africa, particularly with reference to Ubuntu. As far as I know, this text has not yet been read in the light of African philosophy. Of the Sitz-im-Leben of Isaiah 58, Venter (2012:8) writes that "although there is general agreement that much of Isaiah 56-66 was composed during the first century of Persian rule over Judah, uncertainty still remains as to the circumstances under which the material was created and collected" (cf. Smith 1995:206). According to Venter, the divisions and tensions in Yehud caused by social injustice form the background of Trito-Isaiah (Is 56-66). In an attempt to reconstruct the social reality that is both reflected and concealed by the biblical text of Trito-Isaiah, Blenkinsopp (2003:39) has also argued that Isaiah 56-66 describes the actual conditions within the postexilic community in the mid-fifth-century BCE Yehud. Enthused by Blenkinsopp's interest on the reconstruction of the social realities reflected in ancient texts, this article aims to explore the Sitz-im-Leben of Isaiah 58, but from the perspective of Ubuntu. On the methodological level, the discussion will be based on academic literature and will consider the subject of African philosophy in South Africa before probing the possible Sitz-im-Leben of Isaiah 58.

\section{African Philosophy in South Africa as the Basis for a Hermeneutic Enthused by Ubuntu}

The relevance of African philosophy is not foreign to the field of the Old Testament studies. Gericke and Masenya (ngwan'a Mphahlele), among others, have convincingly explored the concept of Ubuntu as an aspect of African philosophy, and their contribution will be considered in this article alongside the views of Steve B Biko and Mogobe B Ramose on Ubuntu. 
African Philosophy in South Africa's Old Testament Scholarship

In a remarkable book, The Hebrew Bible and philosophy of religion, Gericke (2012) engages with the works of Henry Odura Oruka (1981) and Fidelis Okafor (1997), among others, to offer valuable insight on African philosophy. He argues that "methodological and conceptual debates in African philosophy are things that biblical scholars can learn from when seeking to address the controversy regarding the relationship between the Hebrew Bible and philosophy" (Gericke 2012:160). Moreover, he calls for the acceptance of African philosophy as a philosophy in its own right as it validates the idea of ancient Israelite philosophy of religion (Gericke 2009:327; 2012:152). Gericke seems to suggest that if African philosophy enjoys a positive reception among the philosophers, so should the ancient Israelite philosophy of religion among the biblical scholars. The point here is to highlight some of the conceptual debates in African philosophy that Gericke finds plausible. That a number of scholars in the field of biblical studies "harbour serious reservations about the involvement of philosophy in the study of ancient Israelite religion" is therefore besides the point (Gericke 2009:343; cf. Barr 1999:146-174).

On the idea of ethno-philosophy, ${ }^{1}$ one of the four trends in African philosophy distinguished by Oruka, the others being philosophical sagacity, literary/artistic philosophy and hermeneutic philosophy, Gericke agrees that African philosophy consists of a set of shared beliefs (Gericke 2012:154; Oruka 1981:1-7). Thus, it is generally accepted that African thought or philosophy is a communal philosophy rather than the philosophical thought of an individual. With regards to the Japanese context, Gericke also supports Okafor's proposal of 'folkness' and 'communal mind' as characteristics of 'Afro-Japanese Ethno-philosophy' (Gericke 2012:155; Okafor 1997:363-381). Interestingly, communalism as opposed to individualism is underpinned by the African wise saying Umntu ngumntu ngabantu, "A person is a person through other persons". In addition it is noted that philosophical sagacity "concerned itself with daily problems and issues common to every human being, for instance the existence of a Deity, life, knowledge, and death" (Gericke 2012:156). No doubt, philosophical sagacity could be viewed as a contextual philosophy as it is concerned with common problems and issues experienced by people. Thus, based on Gericke's contribution to African philosophy, the idea of communalism which is underpinned by Ubuntu, folkness as well as the concern about the problems of injustice experienced by people is plausible. Thus, the preceding ideas will form an integral part of the aspect of African philosophy which will be employed as a reference in the construction of the Sitz-im-Leben of Isaiah 58 and the interaction between the text of Isaiah 58 and the South African setting.

It is argued that scholarly discussions on ethics in the Hebrew Bible have often neglected "issues related to analytical ethics (i.e., concerns with what moral philosophers call metaethics)". ${ }^{2}$ Metaethics in the context of the Hebrew Bible is concerned with moral thought, talk, and practice in ancient Israel. On the issue of 'Divine Command Theory' in the Hebrew Bible, Gericke (2010:156) notes that in "ancient Israelite religion the divine will was assumed to be the ultimate foundation of morality". Put differently, the consideration of human actions as morally good was solely dependent on whether such actions were commanded by YHWH. From an ideological (philosophical) point of view, it

Okafor (1997:363-381) defines ethno-philosophy as being 'the reasoning or thinking that underlies the existential outlook, the patterns of life, belief system, aesthetic and moral values, (and) customary laws and practices of a particular people'.

2 Gericke 2010:153; See also Otto (1994:21); Barton (2003:45). 
must be noted that the actions considered to be morally good could have been ideologically prescribed by a certain class or race, enabling us to subject the text's ideology to a rigorous sociological analysis in order to de-ideologise the text (cf. Prior 1997:34; Farisani 2002:297). However, the interest of this article does not lie in primarily reading the text from an ideological perspective. Significantly, the provision of the Ten Commandments supports the view that the consideration of human actions as morally good was solely dependent on the 'Divine Command Theory'. It would thus be interesting to read Isaiah 58 from the perspective of metaethics in order to highlight possible immoral actions that triggered moral thought and talk in post-exilic Yehud.

Regarding the view that African philosophy comprises stories, legend, sayings, proverbs and songs, Masenya (ngwan'a Mphahlele)'s use of African proverbs (2011:83; cf. Gericke 2009:327) is noteworthy. She employs the Northern Sotho saying, Motho ke motho ka batho, which means, "I am because we are", or "we are because I am", to argue that, "Taking the Botho/Ubuntu concept seriously implies that the liberation of all African women in South Africa calls for the involvement of all South Africans irrespective of their race, ethnicity, gender and socio-economic class among others" (2011:83). In this case, the African philosophy of Ubuntu is said to offer liberating possibilities - human dignity - to many South African women who are oppressed. For Masenya (ngwan'a Mphahlele), humaneness or human dignity, a term she prefers, problematises the issue of poverty as it suggests that poverty deprives people of their dignity. The proverb Molomo ge o eja o roga wo mongwe which is literally translated as, "A mouth which eats, swears at the one which does not eat" shows how the dignity of the poor is often at stake in a situation of poverty (Masenya (ngwan'a Mphahlele) 2012:457; cf. Rakoma 1970:178). Masenya (ngwan'a Mphahlele) (2012:453) also points out that, "The African ancestor was right when he lamented that moroto wa tšhego, o elela le leoto, the urine of scarcity flows along the (female) leg in his/her attempt to portray the harsh reality of perpetual poverty". No doubt, African philosophy, specifically Ubuntu, refutes the inhumaneness that poverty creates, particularly among the majority of South Africans.

Moreover, the affirmation of humanity which is expressed in the philosophical concept of Ubuntu through the slogan "Black is beautiful" (Masenya (ngwan'a Mphahlele) 2014:13; Woods 1978:192) is both a protest and an affirmation, since blackness was not associated with anything beautiful or good in the colonial and apartheid eras in South Africa (Masenya (ngwan'a Mphahlele) 2014:5). Black South Africans were viewed as less than human (Boesak 1977:26; Vellem 2012:348; Dolamo 2013:6). Therefore, the slogan opposed the imposition of the portrayal of colonists as superior to the 'black' race which subsequently was created out of black South African second class citizens (Vellem 2012:348; Dolamo 2013:6). In line with Vellem's observation that blacks were relegated to the level of second class citizens, Saayman also links the issue of poverty to the perception of black South Africans as being less than human (Saayman 2011:178; cf. Vellem 2012:348). The above views clarify the understanding of Ubuntu in the context of socioeconomic injustice.

\section{Steve B Biko and the Black Consciousness Philosophy}

The Black Consciousness philosophy insists on redressing the oppression of black South Africans based on race (Biko 1979:29; 2004:49; cf. Goba 1986:66; Tshaka 2010:540). Racial oppression of black South Africans under the colonial and apartheid systems led to the formation of the Black Consciousness movement which insists on redressing the effects of racism. Whilst the Black Consciousness philosophy identifies ways in which white 
people oppressed black people in apartheid South Africa, it also critiques the complicity of black South Africans.

Noteworthy, therefore, is Biko's observation of the complicity of black South Africans in their situation of oppression. In a sense, he holds black people accountable for their own oppression because they allowed racism to advance in South Africa (Biko 1979:29). It is interesting that Biko does not blame white people for the oppressive effects of racism on black South Africans; neither does he portray blacks as being bitter towards the apartheid government for the oppression of black South Africans. Based on Biko's view of the Black Consciousness philosophy, the argument that it was the responsibility of the oppressed to resist oppression is compelling (Wilson 1991:23).

Moreover, the Black Consciousness philosophy aims to rid black South Africans of the shackles that have bound them to perpetual servitude (Biko 1979:29; Biko 2004:49). In other words, this philosophy seeks to liberate black South Africans from both their inferiority complex and the servitude mentality which led to their acceptance of oppression. This philosophy was born out of the need to address the sense of inferiority and worthlessness among the oppressed black South Africans that came with the designation of being 'black' which was regarded as a symbol of sinfulness and ugliness (Himes 1971:55; Duncan 2013:61-62). The realisation of the contribution of racism to self-hate resulted in the slogan, 'Black is beautiful' which challenged self-negation - a kind of feeling of selfcensure on the part of the black man and woman (Woods 1978:191; 1987:55). In other words, the slogan challenged self-hate and self-alienation as it sought to enjoin black South Africans to love themselves (Masenya [ngwan'a Mphahlele] 2008:120).

\section{Mogobe B Ramose's Thesis on African Philosophy through Ubuntu}

On the issue of African philosophy and Ubuntu, Ramose offers an interesting contextual perspective. First, he argues "that reconciliation as a legislative Act was a still born because of its objective reinforcement of the poverty and wealth divide. Reconfiliation is more suitable for the advancement of nation-building in South Africa" (Ramose 2012:20). He borrows the term 'reconfiliation' from Anthony JV Obinna who reasons that:

The word 'reconfiliatory' which the computer mistakes for 'reconciliation' may be unfamiliar, but it is not totally strange. 'Re-con' the first part in the word 'reconfiliation' means to bring together. 'Filiation' the second part has a relationship with the words 'filial' and 'affiliate' both of which evoke a sense of belonging that approximates that of son or daughter in a family. 'Filius' and 'Filia' are the Latin for son and daughter respectively. Much more directly and, as I will use it in my talk, the word 'reconfiliation' with verb forms refiliate, confiliate and reconfiliate describes and defines the fact of granting, effecting, regaining, and reclaiming the right of sonship and daughtership in a family fellowship with other sons and daughters of the family. Though reconfiliation is closely related to reconciliation it adds an absolute dimension to the peace-making and harmonising thrust of reconciliation by emphasising the equal dignity of all persons who need to be reconciled (Obinna 2003:2).

Thus, 'reconfiliation' refers to a way of life through which the persons who are reconciled are not only brought to live together but also led to share equal right to dignity. In this way of life, the value of equality is crucial. Unlike Obinna, however, Ramose employs the term 'reconfiliation' interchangeably with Ubuntu. For instance, he concludes his article entitled, "Reconciliation and Reconfiliation in South Africa" with the statement: "...I have proposed the option for reconfiliation in part because it is the lived and living experience of those in the margin of South African society" (Ramose 2012:37). In other words, Ubuntu 
(reconfiliation), as a lived and living philosophy, is logically illustrated by the way people are typified at a relational level by the shared equal right to dignity. Therefore, based on Ubuntu, African philosophy refutes the persistent unjust, unequal and inhumane poverty that is commonly experienced by black South Africans. Moreover, given Ramose and Obinna's idea of 'reconfiliation', it would be logical to question the legitimacy and integrity of any process of reconciliation which fails to offer equal right to dignity to the two parties involved in such a process. In other words, if inequality persists between the subjects of reconciliation, then the nature of the reconciliation process becomes suspect and inconclusive.

The differing arguments presented by Letseka and Venter in contrast to Ramose on Ubuntu, warrant a closer look at the relationship of Ubuntu to the other trends of philosophy. As mentioned, Letseka and Venter (2012:4) claim that "Ubuntu is only part of ethno-philosophy". This claim is based on the understanding that there are more trends of African philosophy than ethno-philosophy (as Oruka argues) which include philosophical sagacity. No doubt, to conflate African philosophy with ethno-philosophy, as the students did, is to devalue the other three trends. Thus, it is reasonable to argue that Ubuntu underlies all African philosophical philosophy. Although I accept Oruka's categorisation of African philosophy into various trends, I sympathise with Ramose's view on Ubuntu being an African philosophy against Letseka and Venter's claim that Ubuntu is only a worldview underlying all African philosophical thinking and therefore cannot, on its own, be regarded as a philosophy. The reason for being sympathetic to Ramose is based on the relationship of Ubuntu to the so-called other trends of African philosophy. Apart from the nationalistideological philosophy and professional philosophy (trends that do not form part of the interest and scope of the present research), ethno-philosophy, philosophical sagacity and metaethics are related to Ubuntu. One may ask: Is Ubuntu a fifth trend in addition to Oruka's four trends of African philosophy, namely ethno-philosophy, philosophic sagacity, nationalist-ideological philosophy and professional philosophy? In my view, the relation of Ubuntu to the other trends places it at the level of a framework or umbrella within which such trends operate. Thus, I agree with Ramose. For instance, Ubuntu's interesting contextual perspective is not different from philosophical sagacity which according to Gericke (2012:156) concerns common problems and issues experienced by people. Moreover, based on the reference to a way of life in Ubuntu an ethno-philosophy which concerns the patterns of life and morality, may be caricatured in Ubuntu. Based on the preceding similarities and caricatures, it is difficult not to be sympathetic to Ramose.

The philosophical contributions of selected Old Testament scholars and African philosophers warrant consideration of a hermeneutics that is enthused by Ubuntu. On a hermeneutical level, the thoughts and values that emanate from the discourse of African philosophy may be employed as a point of reference in our navigation of the possible lifesetting for Isaiah 58. Such thoughts and values include:

- communalism as opposed to individualism,

- moral thought, talk and practice,

- concern with the problems and issues experienced by people,

- inhumanness that poverty creates,

- redress of oppression,

- equal right to dignity. 


\section{Some Observations on the Possible Sitz-im-Leben of Isaiah 58}

According to Ben Zvi (2013:378), the addressees of Trito-Isaiah, that is, the intended readership of the Book of Isaiah, were located in post-exilic Yehud in the late Persian period, which he refers to as the 'restoration' period (Ben Zvi 2013:377; cf. Hanson 1979:60; Dim 2005:371; Venter 2012:2). Not only does Isaiah 56-59 show that the themes of comfort and healing for the whole nation are extended to the oppressed, it equally provides us with a theme of restoration which presupposes the reality of oppression in postexilic Yehud (Hanson 1979:77-79; Sweeney 1988:185; Venter 2012:7). The logic here is this: there is often a life-setting which triggers a thought or a theme. In a reverse order, one may deduce a possible life-setting from the themes or thoughts embedded in the text of Isaiah 58. As noted earlier, the reconstruction of the possible Sitz-im-Leben of Isaiah 58 will be attempted via the thoughts and values that emanate from the discourse of African philosophy.

In the text of Isaiah 58, we are presented with a situation in which traditional religious practices, namely, fasting, sacrifices and Sabbath were treated as a mere formality (cf. Ben Zvi 2013:382). However, this study will not focus on that situation or on the fact that religious leaders were self-indulgent and neglected their responsibilities (cf. Ben Zvi 2013:382). It must be said though that despite the fact that fasting, sacrifices and Sabbath were practiced they did not result in the ethical life expected and for that reason the present study will examine three issues, namely, first, moral regeneration; second, socio-economic injustice and oppression; and third, conflict in Yehud.

\section{Moral Regeneration - Immorality}

The allusion to sins (Is 58:1) and evil (Is 58:9) suggests that Trito-Isaiah was concerned with the issues of morality or what moral philosophers call metaethics. Ben Zvi (2013:382) holds that "there are few if any signs of moral regeneration" in Isaiah 58, and this validates the view that Trito-Isaiah was concerned with issues of morality which include murder, oppression of workers and injustice in the judicial system, pointing of the finger, and the speaking of evil (cf. Ben Zvi 2013:382). Put differently, the morality of the addressees of Isaiah 58 was questionable; hence, the text opposes 'sins' and 'evil'.

It is also noteworthy that the allusion to sins in Isaiah 58:1 is followed by a reference to the 'ways' and 'ordinance' of YHWH (Is 58:2). As Gericke (2010:156) would argue, "the ways and ordinance of YHWH or rather the divine will of YHWH is assumed to be the ultimate foundation of morality". This argument is in line the Divine Command Theory. This means that, the 'sins' and 'evil' alluded to in Isaiah 58, are in fact set against the divine will of YHWH. The logic here is this: that which is in opposition to the divine will of YHWH in terms of the Divine Command Theory constitutes immorality. Based on the idea of "moral thought, talk and practice" that is grounded in metaethics and on the reference to 'sins' and 'evil,' as well as on Ben Zvi's observation of the rare signs of moral regeneration in Isaiah 58, it becomes clear that Trito-Isaiah was addressing the issue of immorality in the chapter.

Moreover, the concepts of humaneness and wholeness are viewed as being integral to Ubuntu in South African scholarly literature (Ramose 2014:124). That is, because epistemology is empty without practice; the view that ethics and morality provide a practical content to epistemology seems to be plausible. This means the idea of humaneness and wholeness in Ubuntu is inseparable from the issues of ethics and morality, as Ramose (2014:124) would argue. It would be reasonable to assume then that one of the concerns among the addressees of Isaiah 58 is related to 'humaneness' and 'wholeness', and it is not 
surprising that the themes of comfort and healing in Isaiah 58 are presented in a holistic manner. Both humaneness and wholeness are presented as emanating from the act of redressing 'sins' and 'evil'. In other words, moral regeneration forms part of holistic restoration in post-exilic Yehud.

\section{Socio-economic Injustice and Oppression}

It is generally accepted that Isaiah 58 addresses the issue of injustice in post-exilic Yehud (Smith 1995:205; Berges 1998:61; Groenewald 2011:98). Interestingly, Trito-Isaiah's concern for the challenges experienced by people in post-exilic Yehud, particularly with regard to injustice, resonates with the notion of philosophical sagacity. This notion "represents an individualist version of ethno-philosophy that pertains to the beliefs of certain special members of a community" (Gericke 2012:155). In the African context, these beliefs include the thoughts produced by the African sages. In this case Isaiah 58, similar to philosophical sagacity, shows concern for the challenges experienced by people. First, on the issues of socio-economic injustice reflected in the text in question, Ben Zvi (2013:382) notes that Isaiah 58:6-10 hints at a situation in which there was no thought for the poor in post-exilic Yehud (cf. Is 59:1-15a). Of significance to the modern reader of Isaiah 58 drawn to Ubuntu is the clue in the text that shows that the addressees of Trito-Isaiah experienced inhumaneness resulting from poverty. Manzo's (2014:35-50) position that Isaiah 58:1-9a presents a call to justice in terms of feeding the poor also confirms that the addressees of Trito-Isaiah in post-exilic Yehud experienced poverty.

Again, the idea of sharing bread with the hungry adds a curious dimension to the poverty detected in Isaiah 58, as it presupposes that the addressees of Trito-Isaiah were not sharing their resources with the less-privileged in the community. The refusal to share their bread also presupposes an individualistic and capitalist approach to economic resources rather than a communal one. It equally suggests that the lack of communalism among the addressees of Isaiah 58 entrenched the inhumaneness resulting from poverty. From an African philosophical point of view, the idea of sharing one's bread with the hungry is captured by the African proverb, Bana ba motho ba ngwathelana hlogo ya tsie, which means, "The siblings share the head of a locust". The proverb echoes the idea of the equitable sharing of resources in order to alleviate poverty in a situation where poverty is perpetuated by the self-enriching tendencies on the part of the rich (Is 58:7,10). Moreover, the phrase "serving your own interest" which is mentioned twice in Isaiah 58 (vv. 3,13) confirms that self-enriching tendencies by the rich which perpetuated poverty are implied in the text in question.

Trito-Isaiah further expresses concern about the oppression of the working-class people in post-exilic Yehud. The reference to oppressed workers in Isaiah 58:3 supports Ben Zvi's (2013:382) claim that there was rampant injustice in the workplace at the time Trito-Isaiah was composed. Textual evidence from Isaiah 58:3 shows that the working-class people were exploited. Post-exilic literature also attests to the ill-treatment of the working-class people in Yehud. For instance, Nehemiah 5:1-13 and Leviticus 25:10, 39-40 and 54 present scenarios in which Judean landowners were forced to sell their ancestral estate and they ultimately became indentured slaves working on the estate of other wealthy Judeans (Nihan 2011:131). Given the idea of redressing oppression that emerged from the discussion of African philosophy above, a modern African reader of Trito-Isaiah would be sympathetic to the concern about the oppression of the working-class people in post-exilic Yehud which is detected in Isaiah 58. 


\section{Conflict in Yehud}

Venter (2012:8) has argued that in post-exilic Yehud "the conflict occurred between differrent social groups; Trito-Isaiah takes the part of the oppressed and reprimands the upper class for its political and economical oppression". No doubt, the allusion to quarrel and fight, as well as to the idea of striking one with a wicked fist in Isaiah 58:4 hints at a conflict among the addressees of Trito-Isaiah. The pointing of the finger and the speaking of evil in verse 9 equally suggest a situation of conflict. Moreover, that there are few if any signs of equal right to dignity in Isaiah 58 presupposes the possibility of conflict between the rich élites and those who were homeless (v.7), without clothes (v. 7), oppressed (vv. 3, 6), hungry - poor (vv. 7, 10).

Römer $(2005: 169,171)$ correctly points out that the Persian ideology of segregation made a distinction between people based on class and identity. ${ }^{3}$ The distinction between the walled cities and village houses, which clearly marked a distinction between the Golah élites (who returned from the Babylonian exile) and the people of the land (the poor from rural Yehud) supports this view (cf. Lev 25:29-34). Moreover, scholars have noted that throughout the Monarchic, Neo-Assyrian and Neo-Babylonian periods and even during the Persian period, large portions of agricultural land which produced wealth were owned by the rich and powerful élites who resided in the cities (Knight 2011:202). Thus, the rich élites most likely lived in cities and their productive land was managed by the poor Israelites. That means their wealth was generated by the poor. Given the issue of classism, economic inequalities and the adverse treatment of the poor in rural Yehud, McNutt's (1999:200-202) observation of the conflict between the returning exiles and those who remained in Yehud, ${ }^{4}$ namely the so-called 'people of the land' would make sense. As noted earlier, a conflict is implicitly suggested in Isaiah 58.

\section{Conclusion}

Based on views from the fields of the Old Testament, philosophy and African studies, this article has argued that African philosophy, particularly Ubuntu, can shed light on the reading of the ancient biblical text in South Africa. Significantly, not only does this contribution examine African philosophy in the context of Hebrew Bible studies, but it also provides a reading of the text of Isaiah 58 that is enthused by Ubuntu. On a hermeneutical level, the thoughts and values that emanate from the discourse of African philosophy are identified as communalism (as opposed to individualism); moral thought, talk and practice; concern about the problems and issues experienced by people; inhumaneness resulting from poverty; redress of oppression; and equal right to dignity. These thoughts and values were employed as a point of reference in the argument that the issues of immorality, socioeconomic injustice and oppression, and of conflict in Yehud, form part of the historical context of Isaiah 58 .

However, class may be viewed as a category of identity such as race and ethnicity.

Noteworthy: the main source of conflict was between the exiles and the people who remained on the Land who were the real Israelites which also determined who had easy access to economic resources. 


\section{BIBLIOGRAPHY}

Barton, J 2003. Understanding Old Testament Ethics, Westminster John Knox Press, Louisville, KY.

Ben Zvi, E 2013. "Isaiah, a Memorable Prophet: Why was Isaiah so memorable in the late Persian/early Hellenistic Periods? Some Observations", in DV Edelman \& E Ben Zvi (eds.), Remembering Biblical Figures in the late Persian and early Hellenistic Periods, pp. 356-383, Oxford University Press, Oxford.

Berges, U 1998. Das Buch Jesaja: Komposition und Endgestalt. Herder, Freiburg.

Biko, SB 1979. I write what I like, Heinemann, London.

Biko, SB 2004. I write what I like, Picador Africa, Johannesburg.

Blenkinsopp, J 2003. Isaiah 56-66: A new Translation with Introduction and Commentary, Doubleday, New York.

Boesak, A 1977. Farewell to Innocence, Ravan Press, Johannesburg.

Dim, EU 2005. The Eschatological Implications of Isa. 65 and 66 as the Conclusion of the Book of Isaiah, Peter Lang, Bern.

Dolamo, R 2013. "Botho/Ubuntu: The heart of African ethics", Scriptura 112(1):1-10.

Duncan, GA 2013. "Passive-aggressive Resistance against Apartheid at the Federal

Theological Seminary of Southern Africa", Acta Theologica 33(1):54-78.

Farisani, EB 2002. The use of Ezra-Nehemiah in a Quest for a Theology of Renewal, Transformation and Reconstruction in the (South) African Context. Unpublished Dissertation, University of KwaZulu-Natal, Pietermaritzburg.

Fikeni, S 2006. "The Nature and Function of izibongo-panegyric Legends: The Case of the Xhosa People of South Africa", in J Kunnie \& NI Goduka (eds.), Indigenous People's Wisdom and Power: Affirming our Knowledge through Narrative, pp. 225-245, Ashgate Publishing Company, Burlington, VT.

Gericke, JW 2009. “'Brave new World’: Towards a Philosophical Theology of the Old Testament", Old Testament Essays 22(2):321-345.

Gericke, JW, 2010. "The Hebrew Bible and Metaethics: A Philosophical Introduction", Scriptura 103:153-163.

Gericke, J 2012. The Hebrew Bible and Philosophy of Religion, Society of Biblical Literature, Atlanta, GA.

Goba, B 1986. "The Black Consciousness Movement: Its Impact on Black Theology", in I Mosala \& B Tlhagale (eds.), The unquestionable Right to be free: Essays in Black Theology, pp. 58-69, Skotaville Publishers, Johannesburg.

Groenewald, A 2011. "Isaiah 1:4-9 as a post-exilic reflection”, Journal for Semitics 20(1):87-108.

Hanson, PD 1979. The Dawn of the Apocalyptic, revised ed., Fortress Press, Philadelphia, PA.

Healy, P 2011. "Rethinking deliberative Democracy: From deliberative Discourse to transformative Dialogue", Philosophy and Social Criticism 37(3):295-311.

Himes, JS 1971. “A Theory of Racial Conflict”, Social Forces 50(1):53-60.

Knight, DA 2011. Law, Power and Justice in ancient Israel, Westminster John Knox Press, Louisville, KY.

Letseka, MM \& Venter, E 2012. "How Student Teachers understand African Philosophy”, Koers - Bulletin for Christian Scholarship 77(1):1-8. 
Manzo, JL 2014. "Feeding the Poor in Isaiah 58:1-9a: A Call to Justice, Mercy, and true Worship”, in SE McGinn, LLE Ngan, AC Pilarski (eds.), By Bread alone: The Bible through the Eyes of the Hungry, pp. 35-50, Augsburg Fortress, Minneapolis.

Masenya (ngwan'a Mphahlele), M 2008. “An African-conscious Female's reading of Steve Biko", in CW du Toit (ed.), The Legacy of Stephen Bantu Biko: Theological Challenges, pp. 114-155, Research Institute for Religion and Theology, University of South Africa, Pretoria.

Masenya (ngwan'a Mphahlele), M 2011. “The Woman of Worth in Proverbs 31:10-31:

Reread through a bosadi (womanhood) Lens", in Faix, Tobias, Wünch, Hans-Georg \& Meier, Elke (eds.), Theologie im Kontext von Biographie und Weltbild, pp. 79-96, Francke-Buchhandlung, Marburg.

Masenya (ngwan'a Mphahlele), M 2012. "Eating the Louse and its Larva! The Indignity of Poverty as embedded within selected African and Old Testament Proverbs", Scriptura 111(3):452-459.

Masenya (ngwan'a Mphahlele), M 2014. "Black (Humanity) is beautiful! Reading Biko and meditating on Psalm 8", Theologia Viatorum 38:1-13.

McNutt, P, 1999. Reconstructing the Society of ancient Israel. Westminster John Knox Press, Kentucky and SPCK, London.

Nihan, C 2011. "Resident Aliens and Natives in the Holiness Legislation", in R Achenbach, R Albertz \& J Wöhrle (eds.), The Foreign and the Law: Perspectives from the Hebrew Bible and the ancient Near East, pp. 111-134, Harrassowitz Verlag, Wiesbaden.

Obinna, AJV 2003. "Roots, Branches ... Graftings and Fruits: The Reconfiliatory Challenge to African-Americans and Humanity at Large", Unpublished paper presented at the Black Catholic Heritage Celebration, Charleston, SC.

Okafor FU 1997. "In Defense of Afro-Japanese Ethno Philosophy”, Philosophy East and West 47(3):363-381.

Oruka, HO 1981. "Four Trends in current African Philosophy", in A Diemer (ed.), Philosophy in the present situation of Africa, pp. 1-7, Franz Steiner Verlag, Wiesbaden.

Otto, E 1994. Theologische Ethik des Alten Testaments, Theologische Wissenschaft 3/2, Kohlhammer, Stuttgart.

Priest, G 2006. "What is Philosophy?” Philosophy 81:189-207.

Prior, M 1997. The Bible and Colonialism: A Moral Critique, Sheffield Academic Press: Sheffield.

Ramose, MB 2012. "Reconciliation and Reconfiliation in South Africa", Journal on African Philosophy 5:20-39.

Ramose, MB 2014. "Ubuntu: Affirming a Right and seeking Remedies in South Africa”, in L Praeg \& S Magadla (eds.), Ubuntu: Curating the Archive, pp. 121-139, University of KwaZulu-Natal Press, Scottsville.

Römer, T 2005. The so-called Deuteronomistic History: A Sociological, Historical and Literary Introduction, T\&T Clark International, London.

Saayman, W 2011. "Being Human together in Democratic South Africa: Umuntu ngumuntu ngabantu”, Journal of Gender and Religion in Africa 17(1):170-188.

Smith, PA 1995. Rhetoric and Redaction in Trito-Isaiah: The Structure, Growth and Authorship of Isaiah 56-66, Vetus Testamentum Supplement 62, Brill, Leiden. 
Sweeney, MA 1988. Isaiah 1-4 and the post-exilic Understanding of the Isaianic Tradition, Walter de Gruyter, Berlin.

Tahko, TE \& Lowe, EJ 2015. “Ontological Dependence”, in EN Zalta (eds.), Stanford Encyclopedia of Philosophy, pp. 1-39, Stanford University, Stanford.

Tshaka, RS 2010. "Do our Theological Methodologies help us to deal with Situations of Violence in Black Communities, specifically Afrophobia", Journal of Theology for Southern Africa 138:124-135.

Vellem, V 2012. "Interlocution and Black Theology of Liberation in the 21st Century: A Reflection", Studia Historiae Ecclesiasticae 38:345-360.

Venter, PM 2012. "Trito-Isaiah, Penitential Prayer and Apocalyptism", Verbum et Ecclesia 33(1):1-12.

Wilson, L 1991. "Bantu Stephen Biko: A Life", in B Pityana, M Ramphele,

M Mpumlwana \& L Wilson (eds.), Bounds of Possibility: The Legacy of Steve Biko and Black Consciousness, pp. 15-77, David Philip, Cape Town.

Woods, D 1978. Biko, Random House, New York.

Woods, D 1987. Biko: The True Story of the young South African Martyr and his Struggle to raise Black Consciousness, Henry Holt Books, New York. 